\title{
The Role of Government in Developing Coffee-based Agro-Industry: Case Study in Pagar Alam, South Sumatra
}

\author{
Wenda Syafitri ${ }^{a} *$ \\ ${ }^{a}$ Bappeda Provinsi Sumatera Selatan, Indonesia
}

INFORMASI ARTIKEL

\section{Article history:}

Dikirim tanggal: 04 November 2016

Revisi pertama tanggal: 22 November 2016

Diterima tanggal: 30 November 2016

Tersedia online tanggal: 19 Desember 2016

Keywords: coffee plantation, agroindustry, role of government

\begin{abstract}
Coffee plantation has become a primary source of income for majority of populations in Pagar Alam. There are approximately 8,745 coffee farmers in this city, most of them are smallholders with average 1 ha of land. Since the globalization has influencing all of the aspects in the world, coffee agro-food system in Pagar Alam is not only involved the local farmers and farm workers who produce the coffee, but also the massive industry that processes, packages, and distributes the coffee to consumers. This research tried to describe the potential of coffee-based agro-industry in the role of creating value-added and increase local farmers' income as well as to analyze some obstacles faced by local farmers in its implementation. This research used quantitative approach by using investment feasibility analysis combined with qualitative approach using interviews. There were 40 respondents involved in this research. The result concludes that coffee-based agro-industry is one of potential livelihoods for the smallholders in Pagar Alam. The investment feasibility analysis showed that processing coffee powder is more profitable than selling unprocessed coffee beans.
\end{abstract}

2016 FIA UB. All rights reserved.

\section{Introduction}

In South Sumatra Province, agricultural sector is a primary sector that has important role. This sector is not only contributes to the GDP but also most of its population still relies their livelihood on this sector. According to Statistical Agency, about 54\% of people in South Sumatra work on agricultural sector. One of the areas that have the potential of agriculture in South Sumatra is Pagar Alam City. Since the whole area of Pagar Alam is a hilly area and surrounded by the mountains of Bukit Barisan, Pagar Alam has fertile soil which suitable for agricultural potential development. In 2013, agricultural sector became the largest contribution to GDP of Pagar Alam with more than 24\%. Majority of the population in Pagar Alam works in agriculture sector. According to Statistical Agency of Pagar Alam,
38.04 percent of Pagar Alam people working in the primary sector and the majority are farmers. Pagar Alam is well-known for the production of plantation crops, especially coffee. Popular as one of largest coffee producer in South Sumatra, Pagar Alam has the biggest number of coffee farmers (8,745 farmers in 2015).

As a main source of livelihood, the price of coffee and the amount of production become very influential on coffee farmers welfare. Since the majority of the population in Pagar Alam work as a coffee farmer (50$65 \%$ of total population are coffee farmer), then the price of coffee and the decline in production will affect their income. From the production side, according to Regional Statistic of Pagar Alam, coffee production in Pagar Alam generally and Dempo Utara \& Dempo Tengah sub district especially has decreased in recent years. In 2015, coffee production in decreased by $25-$ 
$40 \%$ compared to 2013 . This unstable production is caused by the weather and climate condition. Drought that occurred in Pagar Alam has impact on coffee production. As a result, many coffee plants become wither and die; the fruit and the stem dry due to overheating and the land cannot be cultivated because of lack of water. Another factor that is considered to affect the decline of coffee production in Pagar Alam is the use of herbicides and chemical fertilizer during the planting period. Coffee plantations in Pagar Alam classified as non-environment-friendly farming system practices. The farmers use herbicides to eradicate weeds in the farm. They consider this way is easier and faster compare if they use the traditional way to eradicate weeds.

Besides the issue of productivity, price of coffee also affects the income of coffee farmers. The coffee farmers cannot determine the selling price of coffee. Long chain of distribution (supply chain) resulting the farmers cannot sell their coffee directly to consumers, but through a middleman. Middleman is the person who will decide the coffee price received by farmers. This distribution chain has been going on since many years ago. Farmers sell their coffee to the middleman, and then the middleman sends the coffee to the Lampung. Lampung is the neighboring province of South Sumatra. In Lampung, there are large-scale of coffee processing factory such as Nestle and Nescafe. Those companies control the price of coffee. Unfortunately, even though the companies decide the selling price of coffee, the farmers did not receive any incentive (disincentive).

Since most of the farmers still sell their products only in the form of unprocessed coffee beans which is very cheap, farmers lose their opportunities to increase their incomes. The price of coffee beans only 18,000 to 20,000 rupiah (¥165) per kilogram while the price of coffee powder in domestic market is 40,000 to 45,000 rupiah (¥375) per kilogram, or more than 2-fold compared with the price of coffee beans. In fact, development of coffee-based agro-industry is one of the efforts to increase the added value, expanding employment opportunities and increase local farmer's income. Agro-industry plays a fundamental role in employment creation and income generation. Agroindustry can play a strategic role in pro-poor growth strategies, particularly in developing countries where $75 \%$ of the poor live in rural areas. The development of agro-industry can also have an important impact on the local agricultural sector as well as the livelihoods of small holder farmers, provided they can produce on a stable basis, supplying regular quantity and quality (Fatah, 2007). Many scholars highlighted the interdependence between agricultural and industrial development and the potential for agriculture to stimulate industrialization. Resources still must move towards industry and urban centers, but with attention focused on the capital, technological, human resource and income needs of agriculture. This required policymakers to change strategies (Stringer, 2001:8).

Moreover, agro-industry by using local coffee will get an advantage because the raw materials used for processing does not need to be imported while the industry with imported raw material are more susceptible to the impact of the crisis because the price of raw material is dependent on the exchange rate. Therefore, coffee-based agro-industry development is one of appropriate strategies to maximize the agricultural potential in this case coffee potential and develop local industry. Referring to the background above it is necessary to comprehensively comprehend the strategy of coffee-based agro-industry development in order to improve local farmer's income as well as create job opportunity in Pagar Alam. Because of these considerations, the researcher is interested to critically study "The Potential of Coffee-based Agro-Industry in Improving Local Community Welfare (Case study of Pagar Alam, South Sumatra)”.

\section{Theory}

\subsection{Agro-Industry System}

McMichael (1994) mentioned that there are three components of agro-industry systems: production, processing and distribution. These components could not be separated and related to each other. Agro-industry systems include not just the production aspect, but also processing and distribution aspect.

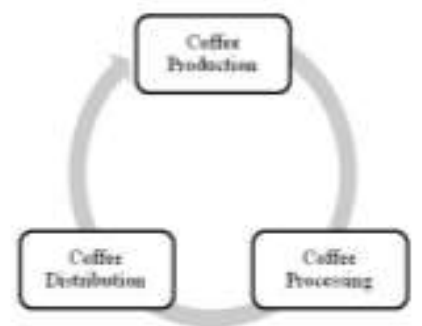

Figure 1 Agro-Industry System

Source: McMichael, 1994

\subsubsection{Production Sector}

Coffee production is closely linked to size of land. The larger size of coffee plantation that is owned by the farmers, then the total of coffee production will increase. Besides depending on size of land, coffee production is also links with technology or innovation adopted. Technology usage applied by the farmers to eradicate weeds or to irrigate their plantation when dry season for instance might influence the coffee production. Besides technology adoption, there are several factors influence coffee production. According to Lassa (2012:606), climate condition is one of the factors for the sustainability of agricultural development 
elsewhere. FAO (2014) also stated that disasters and food insecurity are directly interconnected. Droughts can destroy plantation, coffee processing infrastructure, assets, inputs and production capacity. They interrupt market access, trade and supply chain, reduce income, deplete savings and erode livelihoods. Drought, coffee pests and fungus have a direct economic impact by reducing or eliminating coffee production, by adversely affecting prices, trade, and market access and by decreasing farmer's income and employment.

\subsubsection{Processing Sector}

The decline of agriculture's share in a growing economy is inevitable, particularly its shares in the gross domestic product (GDP) and employment (Anderson, 1987; Anderson and Pangestu, 1995; Antle, 1999; Johnson, 1991; Mellor, 1984 in Fatah, 2007). The logical consequence of this trend is that agriculture's importance in economic development will diminish. The absolute size of agriculture is nevertheless increasing. The view which sees agriculture as merely playing a supporting role to more dynamic sectors (Fei and Ranis, 1961; Hirschman, 1958; Johnston and Mellor, 1995; Jorgenson, 1961; Lewis, 1954; Rosentein and Rodan, 1943; Scitovsky, 1954 in Fatah, 2007) has notably changed to the view that agriculture is important to foster industrialization. Many studies have concluded that agriculture increases export earnings, generates employment, and ensures food security (Alexandratos, 1995; Anwar, 1991; Babu, 2000; Bahri, Suryana and Erwidodo, 1998; Hayami and Kikuchi, 1987; Paukert et al, 1981 in Fatah, 2007). Moreover, it raises the living standard of farmers, generates a domestic market for industrial products, and improves the terms of trade.

Given these characteristics of agriculture, it is important to formulate the appropriate agricultural development policies. The development of efficient rural-based agribusinesses, with appropriate capital intensity and locally specific technology is a strategy that conforms to this new paradigm (Solahuddin, 1999; Suryana et al, 1998 in Fatah, 2007). Agro-industry is one sub-system of agribusiness that has a strategic position in the new paradigm because it has several important roles that help to improve income distribution while also still maintaining growth. Agro-industry is an industry that uses or processes agricultural products as raw materials in its production process (Austin, 1981; Hsu, 1997 in Fatah, 2007). This will help to promote the growth of the agricultural sector through the increased demand for agricultural products. In Pagar Alam, a large percentage of the labor force in the agricultural sector is characterized by low productivity and low income. Agro-industry can break this cycle by providing more productive employment for the rapidly growing rural labor force. The demand from small-scale but labor- intensive agro-industrial can help alleviate rural unemployment (Fatah, 2007).

\subsubsection{Distribution Sector}

Market access in agro-industry system has crucial role. After the farmers harvest their coffee, they have to sell it to gain the income. If the farmers cannot find a buyer to buy their coffee, the farmers will not get the money even their coffee production are increase. Because the farmers want to get money quickly, so they do not want to wait for a buyer who deals better prices. According to William (2014:5), "both supply chains and markets in agricultural products are driven by uncertainty. Coffee supply chains are also characterized by the dynamics of change in production, international competitiveness, international prices that are exacerbated by exchange rate, consumer tastes, etc. Coffee supply chains invariably fail if the willingness of consumers to buy and consume is not matched by the willingness and ability of farmers to produce and supply the coffee".

\subsection{Impact of Globalization on Coffee Agro-Industry}

In recent years, globalization influence in all aspects of the world's including coffee-based agroindustry system. Coffee-based agro-industry not only involve the local farmers and farm workers who produce the coffee, but also the massive industry that processes, packages, distributes and sells it (transnational corporation). Liberalization of trade in agriculture, influence of globalization and no intervention from local governments in domestic markets has resulted in coffee price and quality standards being set by international markets.

The globalization has two sides; First, the side of unprecedented prosperity for a minority of the world investors and consumers. And second, the side of poverty, displacement, job and food insecurity (McMichael, 2007). It is uncontestable that agriculture is the main source of food and income for the majority of the world's poor including in Pagar Alam with 38\% of total population directly depend on the agriculture sector. If all of the aspect of coffee agro-food system still controlled by transnational corporation and aggravated by the negative impact of globalization, it is difficult for local farmers to get a better income and better life.

\subsection{The Importance of Governance for Development}

Governance refers to the manner in which public officials and institutions acquire and exercise the authority to shape public policy and provide public goods and services (World Bank, 2007 in Pomerantz, 2011). Completing the World Bank definition about governance, the following are frequently mentioned as 
part of the 'governance agenda' in the development context:

a) Rule of law, regulatory authority, accountability, transparency, probity and anti-corruption;

b) Government capacity, leadership, organization, institutional structure, scope, and effectiveness;

c) Decentralization, voice, participation, strengthening of civil society and social capital;

d) Democracy, free and fair elections, civil liberties and human rights, freedom of the press; dan

e) A subset of the global governance agenda - the accountability, transparency, probity, organization, legitimacy and effectiveness.

While, Lynn, Heinrich, and Hill (2000) in Frederickson, et al (2012) stated that governance is defined as the "regimes of laws, administrative rules, judicial rulings, and practices that constrain, prescribe, and enable government activity, where such activity is broadly defined as the production and delivery of publicly supported good and services". This definition implies that governance consist of and programmatic structures; statutes and laws; policy mandates; available resources; administrative rules; and institutionalized rules and norms.

In order to achieve the development goals, government made rules and policies in accelerating economic and social welfare. Government has responsibility to fulfill the basic needs of community. But, in reality the government can't solve all the problems facing by community. Public needs increased rapidly, while the capabilities of the government to meet public needs only increased slowly. The inability of the government to meet all the needs of the community caused administrative lag. However, hierarchy's command and control management strategies failed in the face of problems that could not be solved or solved easily by one entity acting alone. Moreover, hierarchy failed entirely as an approach to global and transnational problems (Bingham, 2011). To solve these problems, the government requires other actors to serve the community. This concept called the iron triangle. Iron triangle is mutually supportive relationships among 3 very powerful players in the political process that consists of the state or government, private sector and community. These three elements have different function, but equal position. Each group does some action that will help the other group. Governance requires that participants use different skills from hierarchy. It requires coordination across multiple organizations and stakeholders from public, private, and non-profit sectors that combine in a network to address a common and shared problem (Bevir, 2006 in Bingham, 2011). Governments can work together with private sectors through collaborative governance.

\section{Research Method}

This study was conducted in Dempo Utara and Dempo Tengah sub district, Pagar Alam City. In this study, the researcher collected the data through interviews, observation and documentation. There were 40 respondents involved such as local coffee farmers, local government staff and small-scale coffee processing workers. The method used in this research is qualitative and quantitative approach. Qualitative approach is used in order to get in-depth analysis about potential and obstacles faced by local farmers in developing coffeebased agro-industry. Meanwhile in quantitative approach the researcher used some feasibility analysis of investment. To be able to conduct a feasibility analysis of investment, it is necessary analytical tools. This research applied several analytical tools such as Payback Method, Net Present Value, Cost Benefit Ratio and Profitability Ratio to analyze whether investment in coffee processing industry is profitable or not.

\section{Results and Discussions}

\subsection{Size of Land and Coffee Production}

Pagar Alam is one of the centers of the largest coffee producer in South Sumatra Province. In 2015, coffee production in Pagar Alam reached 7,429 tons; divided in several coffee-producing areas. Dempo Utara sub district is the largest coffee producer area with a production of 2,982 tons, followed by Dempo Tengah sub district with production about 1,763 tons. Coffee plantation plays an important role in the economy of Pagar Alam because most of the local people rely on this commodity as their main livelihood.
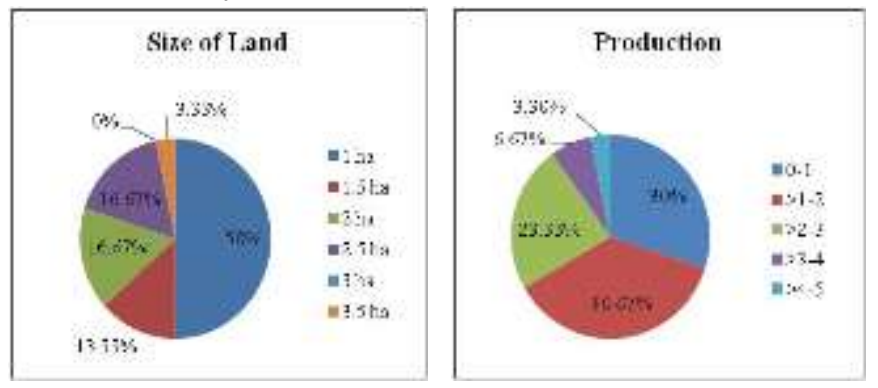

Figure 2 Size of Land and Production

Source: Research result, 2016

Generally, coffee plantation in Dempo Utara and Dempo Tengah categorized as small-scale plantation with size of land ranging between 1-3.5 hectares with average 1 hectare (50\% of the farmers). Size of land was one of the factors that influenced the amount of coffee production. The larger size of land owned by farmers, the more coffee that could be harvested each year. Based on the analysis, mostly more than $60 \%$ of the local farmers produced 1-2 tons of coffee per year; while $23.33 \%$ of the farmers produced $>2-3$ tons of coffee, $10 \%$ of the farmers produced $>3-5$ tons of coffee. 


\subsection{Revenue and Production Cost}

The income that farmers received from selling the coffee beans varies depending on the amount of coffee production. The more coffee production, the more revenue they will receive. This income is also affected by size of land and land ownership. Farmers with small land area will receive less income rather than the farmers who have larger land. Therefore, the farmers who have small land or work in other farmers' land usually have other side job to meet daily needs.

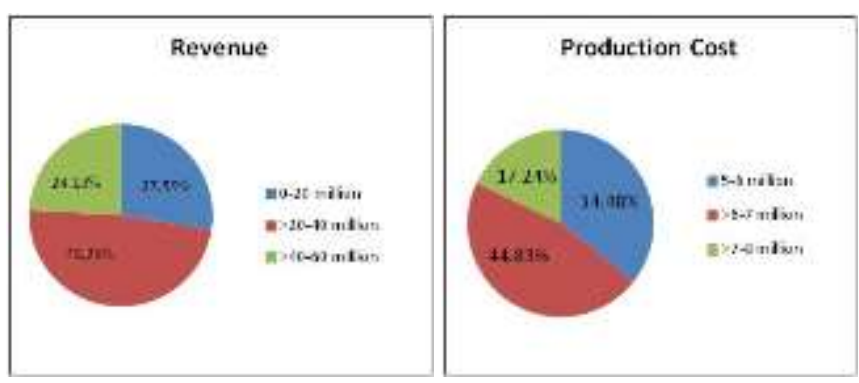

Figure 3 Revenue and Production Cost Source: Research result, 2016

As shown by the figures above, the farmers who have their own coffee plantation, approximately $48.28 \%$ of them have income about $>20-40$ million rupiah per year, while $27.59 \%$ of farmers have income about $10-20$ million rupiah and the remaining about $24.13 \%$ of farmers have income more than 40-60 million rupiah. The income that farmers received from selling coffee still must be reduced by the production cost during the planting season. Mostly about $78 \%$ of farmers typically spent money of 5-7 million rupiah to buy herbicides and fertilizers, while $17.24 \%$ of the farmers spent about $>7-8$ million rupiah per year.

After the income received by farmers deducting with production costs, they would get net income. The net income obtained was used by farmers to meet their living expenses such as food, children, school fee, transportation and so on. Given that the coffee only harvested once a year, then the farmer should manage and use their income for the next 12 months until harvest time next year. The spending patterns of family farmers themselves highly dependent on the income they receive. The higher income received; then the better fulfillment of their daily needs. Farmer's expenditure also depended on the number of family members or dependents of farmers' burden.

\subsection{Potential of Coffee-based Agro-Industry}

Coffee farmers have the opportunity to increase revenue by processing coffee beans into coffee powder or other coffee derivative products. This process is called agro-industry. Agro-industry is an industry that uses or processes agricultural products as raw materials in its production process (Austin, 1981; Hsu, 1997 in Fatah, 2007). In South Sumatra generally and Pagar
Alam especially, a large percentage of the labor force in the agricultural sector is characterized by low productivity and low income. Agro-industry can break this cycle by providing more productive employment for the rapidly growing rural labor force. The demand from small-scale but labor-intensive agro-industrial can help alleviate rural unemployment (Fatah, 2007).

If we look in terms of price, selling price of coffee powder is twofold than selling price of coffee beans. In 2015 , price of coffee beans about 20,000 rupiah per kilogram, while price of coffee powder about 40,000 rupiah per kilogram. This means that farmers would get an opportunity to earn 2 times more than just selling coffee beans. Based on interviews with farmers who had processed coffee powder, coffee farmers in Pagar Alam generally processed the coffee fruit with the dry process. First, they dried coffee fruit under the sun. Drying space could be either a cement floor or pavement. After that, the next step was roast coffee beans, pulverization and then packaging. To be able to process coffee beans into the coffee powder, it is require investment cost as initial capital used to purchase coffee processing machines. The machines can be used within a period of 10-15 years, so that farmers only need to buy once that is only at the beginning of start a business. The details of the capital required to start coffee-based agro-industry is as follows:

Tabel 1 Investment Cost

\begin{tabular}{lccc}
\hline \multicolumn{1}{c}{ Capital } & $\begin{array}{c}\text { Price } \\
\text { (Rp. million) }\end{array}$ & Quantity & $\begin{array}{c}\text { Total } \\
\text { (Rp. } \\
\text { million) }\end{array}$ \\
\hline Roaster machine & 15 & 1 unit & 15 \\
Grinder machine & 5 & 1 unit & 5 \\
Packaging machine & 5 & 1 unit & 5 \\
Drying floor & 5 & 1 unit & 5 \\
Storehouse & 20 & 1 unit & 20 \\
\hline
\end{tabular}

Souce: Research result, 2016

Investment cost for coffee-based agro-industry amounts to 50 million rupiah. These funds are needed primarily for the procurement of machinery such as roaster, grinding and packaging machines, building a warehouse to store raw materials and products, and a drying floor. With this investment, the production can process raw materials (dried coffee beans) as 2,000 kilograms.

By using investment feasibility analysis, the results would be obtained were Payback Method, Net Present Value, Benefit Cost Ratio and Profitability Ratio as shown as table below:

Table 2 Investment Feasibility Analysis

\begin{tabular}{|c|c|c|}
\hline No & Feasibility Analysis & Result \\
\hline 1 & Cost-Benefit Analysis & 2.56 \\
\hline 2 & Profitability Ratio & 3.25 \\
\hline 3 & Net Present Value & 163 million rupiah \\
\hline
\end{tabular}




\begin{tabular}{|c|c|c|}
\hline No & Feasibility Analysis & Result \\
\hline 4 & Payback Period & 2.32 \\
\hline
\end{tabular}

Souce: Research result, 2016

\subsubsection{Cost-Benefit Analysis}

Cost benefit analysis is an analysis is used to evaluate a project. This analysis is a practical way to understand the usefulness of the project. A project is feasible if the ratio of benefits to costs is greater than 1 . For the $\mathrm{B} / \mathrm{C}$ ratio, the result shows that this coffee-based agro-industry is feasible and eligible to run, characterized by a $\mathrm{B} / \mathrm{C}$ ratio $>1$, which amounted to 2.56. This ratio means that at every 1 rupiah spent will generate revenue of 2.56 rupiah.

\subsubsection{Profitability Ratio}

Profitability Index is a method of calculating the feasibility of the project by comparing the amount of the present value of future cash flow divided by the initial investment of the project. Profitability Index (PI), also known as profit investment ratio and investment value ratio. PI is calculated by finding the present value of cash flows that will be received from the investment. After that, it is compared with the total investment of the project. The result showed that profitability ratio is 3.25 , which means that profits earned from processing coffee powder is 3.25 times compared with unprocessed coffee. It is prove that coffee-based agro-industry is profitable in the next 10 years.

\subsubsection{Net Present Value}

Net Present Value is an evaluation method to determine the overall value of a project (or a series of cash flows). The two basic concepts of net present value are (1) that all benefits and costs are calculated in terms of today's currency (that is, present value) and (2) that benefits and costs are combined to give a net valuehence the name net present value (Lalitrojwong, 2010). As we know, the value of money received today is worth more (assuming you can earn interest) than money received in the future. Thus, money received in the future must be "discounted" to estimate its Present Value (Woodroof, 2011). In simply word, this method calculates the difference between revenue and value of money in this time with the revenue and the value of money at the time when the project is completed.

In this research, the researcher had used a discount rate of 12 percent. The purpose of using discount rate was to cover increasing of prices and services, inflation, production fluctuation, etc. With a discount rate of 12 percent was obtained net present value in the next 10 years approximately 163 million rupiah or about 13.5 million per year.

\subsubsection{Payback Period}

Payback period is a method to determine the point in time at which the initial investment is paid off. Using the data from the table above, we could analyze the payback period. The results showed that payback period is 2.32 , which means that within a period of 2 years 3 months initial investment was paid off.

\subsection{Obstacles in Implementing Coffee-based Agro Industry}

Based on the results of analysis, it was found that the majority of coffee farmers did not process the coffee before they sold it. It was only small number of farmers in Dempo Utara and Dempo Tengah who already processed the coffee. That means the farmers had limited choice. The farmers forced to sell their coffee beans through middleman because they did not have the capital to buy the coffee processing machines (to process coffee beans into coffee powder). Furthermore, in order to run coffee-based agro-industry, it was requires continuous production. Continuous production itself was influenced by several factors. Rosenzweig and Hillel (2005) mentioned that weather and climate condition had impact on agricultural productivity. Moreover, they stated that the use of high levels of agrochemicals would also bring negative impacts to environment and would ultimately affect coffee production. In fact, coffee farmers in Pagar Alam still used chemical fertilizer and herbicide in their planting system. They did not aware the impact of chemical usage on their production and environment.

The other obstacles that happened were market access. The farmer had no power to sell the coffee directly to consumer. Even if the farmer had already process the coffee, it was still difficult to find a market for them to sell the coffee powder. However, if we looked in many big cities, there were plenty of cafes that sell coffee. But, most of them controlled by the transnational corporation such as Starbucks. McMichael (1994) revealed that corporation (TNC) control market access and the price, so that local farmer has no power to determine the selling price. If they want to penetrate the international market, the third world countries should follow the mechanism of TNCs. Furthermore, increasingly globalised and industrialized food system is not benefiting smallholder farmers or majority of family farmers. UN data reveal that transnational corporations account for two-thirds of world trade. Fifty of the largest 100 economies are run by TNCs (McMichael, 2007).

\subsubsection{Unstable Production}

Post-harvest processing activities is closely associated with continuous production; because coffee processing business requires a supply of coffee beans as raw material to keeps it running smoothly. If coffee 
production is stable, the coffee processing business can continue to operate. Based on data from BPS in Pagar Alam, coffee production has decreased in the last few years. This is due to several factors including climate condition, fertilizer and herbicide usage and pests.

a) Drought

In Pagar Alam, the temperature and the longer period of dry season affects coffee production. About $76.67 \%$ of farmers said that the drought influence their coffee production. While $23.33 \%$ of farmers said that the drought did not affect the production of coffee. The farmers who said drought did not affect their coffee production have different the location of coffee plantation, their land relatively higher than the other. Some farmers revealed that high air temperatures resulted in less water supply, flowers \& branches die and leaves fall.

This fact is supported by FAO (2014) which also stated that "disasters and food insecurity are directly interconnected. Droughts can destroy plantation, coffee processing infrastructure, assets, inputs and production capacity. They interrupt market access, trade and food supply, reduce income, deplete savings and erode livelihoods. Drought, coffee pests and fungus have a direct economic impact by reducing or eliminating coffee production, by adversely affecting prices, trade, and market access and by decreasing farmer's income and employment".

b) Herbicide Usage

Coffee plant maintenance was conducted by controlling weeds. Control of weeds could be conducted mechanically and chemically. Mechanical way was eradicate grass under coffee trees by using sickles, while chemical way was eradicate grass by using herbicides. In addition, coffee plant maintenance was also conducted by cutting unproductive dead branches, twigs and buds. Based on the survey, the majority of coffee farmers in Dempo Utara and Dempo Tengah, which was about $83 \%$ of them, used herbicides to eradicate weeds. This method was considered by the farmers as the easiest and fastest way compared to the traditional way by using sickle. Moreover, when the rainy season came, the grasses under the coffee trees grew quickly, so if the farmers not immediately weeded, the grass would grow more and more. In the end, the farmers become lazy for weeding by sickle then use herbicides. On average, farmers spent 5 liters of herbicides year. The remaining $20 \%$ of them spend 4 liters, $12 \%$ of them spent 10 liters of herbicide.

c) Chemical Fertilizer Usage

The use of fertilizer was expected to increase coffee production. Fertilizers were used generally contain the elements N, P, K and other micro elements. About $90 \%$ of farmers in Dempo Utara and Dempo Tengah used fertilizer for their coffee crops. The farmer was usually applying fertilizer 2 times in a year. Majority (about $84 \%$ ) of farmers in those two sub districts were using an average of 100 to 200 kilograms a year. Urea and Ponska were the common type of fertilizer use. In fact, the farmer still using chemical fertilizer and not using organic fertilizers such as compost or fertilizer from waste of shell coffee.

\section{d) Pest and Fungus}

Pests are one of the obstacles that can influence coffee production. Most of the farmers stated that they have ever experienced with pest. In Pagar Alam, fruit borer (Stephanoderes hampei) was a type of pest which often attack coffee plants. While the fungus was a disease that most commonly affects the coffee plant. According to Rosenzweig et al (2001) in Rosenzweig and Hillel (2005), pest-crop interactions play a crucial role in agro-ecosystems. Pest problems are very likely to be exacerbated under changing climate conditions since pests tend to thrive in warmer conditions. Even in the current climate, warmer temperature tends to increase average per acre pesticide usage costs for many crops.

\subsubsection{Lack of Capital}

One of the obstacles in developing coffee-based agro-industry for most area including Pagar Alam was lack of capital. Capital was not only needed for largescale coffee industry, but also necessary for the homescale coffee industry. Borrow funds for the capital at the bank was still rarely carried out by farmers. Besides the loan rate at bank was still relatively high, borrowed money at the bank also required guarantee. Farmers also had difficulty to repay bank debt in the future. Therefore, they had no other choice besides selling the coffee beans without processing it.

\subsubsection{Difficult to Access Market}

Agricultural production including coffee is usually expected or assumed to always have a buyer. Consumers are generally expected to always need to buy what is produced. The coffee is produced by the farmers opportunistically in the hope that there is a buyer (William, 2014). Because the farmers want to get money quickly, so they do not want to wait for a buyer who deals for better prices. Hence, they sold the coffee through middleman. Middleman is the people who decide the coffee price received by farmers. For the farmers itself, sell the coffee to middleman is the easiest and the fastest way to get the money. The farmers do not necessary to spend money on transportation costs to bring coffee to the market as a middleman who will pick up the coffee from farmers' farm. This distribution chain has been going on since many years ago. After they bought coffee from the farmers, the middleman would send the coffee to the Lampung. Lampung is the neighboring province of South Sumatra. In Lampung, there are large-scale of coffee processing factory such as 
Nestle and Nescafe. There are also exporter companies such as PT. Indo Cafco in Lampung. Those companies control the price of coffee. Unfortunately, even though the companies decide the selling price of coffee, the farmers did not receive any incentive (disincentive). That means the farmers have limited choice and are forced to do so. The farmers are forced to sell their coffee to the company through a middleman because they have no choice and it is difficult to access the market.

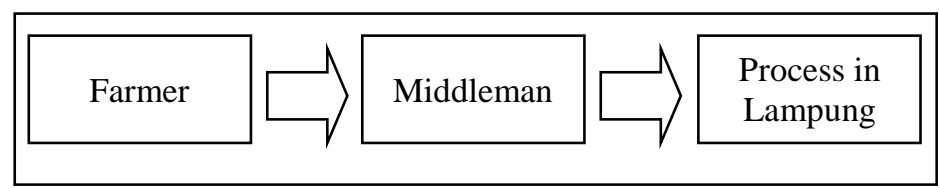

Figure 4 Supply Chain

Source: Research result, 2016

Head of Service of Plantation stated that about 60$70 \%$ of Pagar Alam coffee sold to Lampung in the form of raw material. Then, coffee of Pagar Alam changed its name to coffee of Lampung. This condition was exacerbated since South Sumatra not yet had a largescale coffee factory, due to transportation and inadequate infrastructure (not yet have a large port that could transport the processed coffee in large quantities such as in Lampung).

\subsection{Policy on Agro-Industry Development}

In order to develop local industry, every province in Indonesia, including South Sumatra must prepare and compile the road map of provincial priorities industry development according to Presidential Regulation Number 28 of 2008 concerning the National Industrial Policy. This Presidential Regulation has set a long-term industrial development vision for Indonesia to be a strong industrialized nation by 2025 . The National Industrial Policy was launched in 2008. The development of this policy has referred to and is in line with the RPJPN 2005-2025 (Law 17/2006) and the RPJMN 2005-2009 (Presidential Regulation 7/2005). Through this regulation, central government develops national industry by providing facilities such as fiscal incentives and non-fiscal incentives.

In 2014, the government issued Law No. 3 of 2014 about Industry to replace the old Law No. 5 of 1984 concerning Industry. In this law stated that industry was held with the aiming to:

a) Realize the national industry as a pillar and driver of the national economy;

b) Realize the depth and strength of the structure of industry;

c) Realize self-sustaining industrial, competitive, advance, and also the green industry;

d) Realize the business certainty, healthy competition and to prevent or control the concentration of industry by a group or individual that is harmful to society;

e) Open up business opportunities and expansion of employment opportunities;

f) Creating equal industrial development throughout Indonesia to strengthen and reinforce the national defense; and

g) Improve the prosperity and welfare of the community equitably.

To realize these goals, the government is preparing the National Master Plan for Industrial Development as one of the strategies that must be followed up by every province and district or city in Indonesia. This master plan is a guideline for government and industry players in the planning and construction industry.

To follow up the Central Government Regulations on the National Industrial Policy, South Sumatra provincial government prioritizes the development of downstream industry particularly agriculture-based industry as one of South Sumatra development strategy in the next 5 years in accordance with the South Sumatra RPJMD 2013-2018. South Sumatra has a vision of "Sumatera Selatan Sejahtera, Lebih Maju dan Berdaya Saing Internasional". South Sumatra's vision is realized through four missions that became the main focus as follows:

a) Increasing Economic Growth;

b) Increasing Regional Stability;

c) Improving Equitable Justice; and

d) Enhancing Sustainable Environmental and Disaster Management.

In order to realize the first mission: Increasing economic growth; the strategies and policy implemented in the next five years prioritize to the improvement of production, the expansion of employment opportunities, increasing incomes per capita and development of downstream industry of agricultural products or agroindustry development.

Provincial government policy in RPJMD then is reflected in the Strategic Plan (RENSTRA) of Service of Industry and Trade. As a commitment of provincial governments in developing downstream industry, especially in agro-industry, Service of Industry and Trade has set several missions that support the policy, among others:

a) Increasing the value added and the growth of industrial development;

b) Increasing efficiency of domestic trade;

c) Increasing the competitiveness of non-oil exports; and

d) Improving the management and marketing of agroindustry products.

Even the government has issued several policies to develop agro-industry, but the role of local government is not optimal yet. In term of market access, for instance, 
the local government has not been providing help. Farmers still sell the coffee to middleman. The local government supposed to intervene and helps the farmer to distribute the coffee. But, there are many important roles regarding agricultural supply chain integration that do not involve direct intervention. These include ensuring sufficient competition and minimizing monopoly and collusive practices, enforcing contract law, ensuring the stability of government, minimizing corruption, deregulating markets including labor, finance, currency, capital investment and minimizing inflation and taxes through adequate monetary and fiscal policy (Williams, 2014).

Based on the survey, farmers in Pagar Alam expect the government to be concerned about the price of coffee. Currently the price of coffee is still considered low. To increase the selling price of coffee, the government is expected to accelerate the implementation of agro industry. In order to implement coffee-based agro-industry in small scale, local government can allocate local budget for buy several equipments such as coffee processing machines to farmers' group. Furthermore, in a large scale, local government can invite investor as recourse to solve the lack of capital problem in Pagar Alam. By having capital from investors, Pagar Alam is expected to have its own coffee processing factory so that the coffee of Pagar Alam is not necessary to be sent to Lampung.

Meanwhile in distribution sector, the role of local government is very important. The local government supposed to intervene and helps the farmers to distribute the coffee. However, if the farmers can access the consumer directly, they may get better price and better income. During this time, several programs has been conducted both by local government and supported by central government, but its implementation is poorly managed. In the future, local government should be more active in promoting Pagar Alam coffee products to consumers both within and outside the region. Local government also should pay attention on the repackaging and rebranding the coffee of Pagar Alam to be more known by the public.

\section{Conclusion}

Coffee plantation has become a primary source of income for majority of populations in Pagar Alam. There are approximately 8,745 coffee farmers in this city, most of them are smallholders with average 1 ha of land. In recent years, coffee production in Pagar Alam has been decreased. Drought, chemical fertilizer, herbicide usage and pests have contributed to the declining of coffee production. Moreover, since the globalization has influenced all of the world aspects including coffee agro-food system, there is transnational corporation involvement in supply chain.
In Pagar Alam, majority of the farmers do not process their coffee before sell it so there is no value added that they can get. Since most of the farmers still sell their products only in the form of unprocessed coffee beans which are very cheap, farmers lose their opportunities to increase their incomes. The price of coffee beans is only 18,000 to 20,000 rupiah ( $¥ 165$ ) per kilogram while the price of coffee powder in domestic market is 40,000 to 45,000 rupiah ( $¥ 375$ ) per kilogram, or more than 2-fold compared with the price of coffee beans. Coffee-based agro-industry is one of potential livelihoods for the farmers to increase the income. Based on the investment feasibility analysis, the results showed that coffee-based agro-industry was feasible and eligible to run. Moreover, result of profitability ratio was 3.25, which means that profits earned from processing coffee powder was 3.25 times compared with unprocessed coffee. It is proving that coffee-based agroindustry will profitable in the next 10 years.

However, in order to run coffee agro-industry in Pagar Alam, there are some obstacles. Post-harvest processing activities is closely associated with continuous production; because coffee processing business requires a supply of coffee beans as raw material to keeps it running smoothly. Meanwhile, based on data from BPS, coffee production had decreased in the last few years. This is due to several factors including climate condition, fertilizer and herbicide usage and pests.

In recent years, the temperature and the longer period of dry season in Pagar Alam affect the coffee production. Some farmers reveal that high air temperature results in less water supply, flowers \& branches die and leaves fall. Another factor that is considered to affect the decline of coffee production in Pagar Alam is the use of herbicides and chemical fertilizer during the planting period. Coffee plantations in Pagar Alam classified as non-environment-friendly farming system practices. The use of herbicides and chemical fertilizers will affect soil structure and in turn will affect the amount of production in the long term.

The other obstacles are lack of capital. This is common problem in most developing countries including Indonesia. Borrowing funds for the capital at the bank is still rarely carried out by farmers. Beside the loan rate at bank is still relatively high, borrowing money at the bank also requires guarantee. Farmers also state that they will have difficulty to repay bank debt in the future. Therefore, they have no other choice besides selling the coffee beans without processing it.

Dealing with these problems, several efforts are needed to conduct, especially the role of local government. The farmers wish that local government can help them to access wider market with higher prices. Then, repackaging and rebranding the coffee product 
can be an option to increase the price. Furthermore, local government through Agricultural Extension Board can facilitate the farmers to provide information relates to coffee plantation and increases productivity. To increase coffee productivity for instance, the farmers should reduce chemical and herbicide usage and start to implement environment-friendly farming system. The farmers can do soil restoration by changing chemical fertilizer usage with fertilizer from waste of coffee shells.

\section{References}

Bingham, Lisa Blomgren. (2011). "Collaborative Governance," in Handbook of Governance, Edited by Mark Bevir. The Sage Publication. USA.

FAO. (2014). Understanding the drought impact of El Nino on the global agricultural areas: An assessment using FAO's Agricultural Stress Index (ASI). Rome: Food and Agriculture Organization of the United Nations.

Fatah, Luthfi. (2007). The Potentials of Agro-Industry for Growth Promotion and Equality Improvement in Indonesia. Lambung Mangkurat Universiy, South Kalimantan.

Frederickson, George, et al. (2012). The Public Administration Theory Primer. Westview Press, USA.

Lalitrojwong, Pattarachai. (2010). Appendix C: Calculating Net Present Value, Payback Period, and Return on Investment (ROI). Available at Https://www.it.kmitl.ac.th/ pattarachai/SAD/978 1423902287_AppC.pdf/ [Accessed 7 April 2016].

Lassa, Jonatan A. (2012). Emerging "Agricultural Involution" in Indonesia: Impact of Natural Hazards and Climate Extremes on Agricultural Crops and Food System. Sydney: Institute of Resource Governance and Social Change and Associate Research Fellow.

McMichael, Philip. (1994). The Global Restructuring of Agro-Food Systems. Cornell University Press: Ithaca and London.

McMichael, Philip. (2007). Development and Social Change, a Global Perspective. Pine Forge Press: Cornell University.

Pomerantz, Phyllis R. (2011). "Development Theory," in Handbook of Governance, Edited by Mark Bevir. The Sage Publication, USA.

Rosenzweig, Cynthia and Daniel Hillel. (2005). Climate Change, Agriculture and Sustainability, in Climate Change and Global Food Security, edited by R. Lal et al. CRC Press: Taylor and Francis Group, New York.
Stringer, Randy. (2001). How Important are the 'NonTraditional' Economic Roles of Agriculture in Development?. Australia: Adelaide University.

Williams, John. (2014). Agricultural Supply Chains and the Challenge of Price Risk. New York: Routledge: Taylor and Francis Group.

Woodroof, Eric A. (2011). How to Use Net Present Value to Your Advantage: Why Simple Payback is not always "fair". Available at Https://ProfitableGreenSolutions.com/ [Accessed 12 May 2016]. 